\title{
The dissemination of Salmonella typhi, S. paratyphi $A$ and $S$. paratyphi $B$ through the organs of the white mouse by oral infection
}

\author{
BY C. B. GERICHTER \\ Vaccine and Serum Institute, The Government Central Laboratories, \\ The Ministry of Health, Jerusalem
}

(Received 21 May 1960)

\section{INTRODUCTION}

The dissemination of Salmonella strains through the organs of the white mouse by oral infection has been investigated by several research workers. Although most investigators contend that the intestine is the chief site of entrance to the tissues for the bacterium, diverse opinions exist with regard to the mode of dissemination from the intestine to the various organs. Mueller (1912), experimenting in infections per os with several salmonella strains ('paratyphus' strains), came to the conclusion that the passage from the intestine to the various organs is dependent both on the strain and also on the dose. If the strain is extremely virulent for the white mouse and the dose is a large one, the bacteria pass from the intestinal lumen directly into the blood stream-resulting in a primary infection of the blood. If the strain is of low virulence, the infection spreads by way of the lymphatic system which carries it to the blood and organs. The next stage, according to Mueller, is a secondary bacteraemia.

Ørskov, Jensen \& Kobayashi (1928a) and Øskov \& Moltke (1928b) also observed a difference between the dissemination of virulent and non-virulent strains, but their conclusions differ from those of Mueller. They claim that both the virulent and the non-virulent strains pass from the intestine into the lymphatic system. Whereas the virulent strain- $S$. typhimurium-spreads from the regional lymph nodes via the thoracic duct to the blood stream which carries the infection into the organs (liver and spleen), the non-virulent strain-S. paratyphi B-causes a localized infection in the mesenteric nodes where the bacteria persist for several weeks. Similar findings were made by Krough-Lund (1928) experimenting with S. typhi (strain 555) which also remained in the mesenteric nodes and did not spread any further from there.

Seiffert (1928), on the other hand, found bacteria in the blood, lymph nodes and in body organs several hours after infection; his findings are similar to those of Mueller.

Kligler \& Olitzki $(1930,1931)$ investigated the course of oral infection with S. enteritidis, a strain of medium virulence for the white mouse. From their findings, they concluded that the infection does not induce a primary bacteraemia but tends to be localized in the first stage in the mesenteric nodes, from which the bacteria afterwards enter the blood stream and organs. They consider the mesenteric 
nodes to be the main region of infection, and they actually are the first site of infection and the last in which bacteria may still be found.

Another point of disagreement among scientists is the fate of salmonella bacteria after reaching the intestinal lumen. Mueller (1912) found bacteria in the intestine during all stages of infection. Ørskov et al. (1928a), on the other hand, claim that the bacteria disappear entirely from the intestine shortly after the oral infection and only a small number succeed in passing through the intestinal wall (the mode of passing is unknown).

Sieffert (1928) noted the presence of these bacteria in the intestine during all stages of infection, and he claims that only the non-virulent strains speedily disappear from the intestine.

Kligler \& Olitzki $(1930,1931)$, who did extensive work on the subject, proved that the bacteria tend to remain in the intestine during all stages of infection, a phenomenon not related in any way to the virulence of the strain. Working with S. enteritidis, they showed that the site of infection in the intestine varies during the different stages of infection. During the first stage - the incubation periodthe bacteria remain in the lower part of the intestine. During the next stage-at the peak of infection - the bacteria may be found mostly in the upper part of the intestine and during the third stage-carrier state-the bacteria are localized solely in the upper intestine.

\section{MATERIAL AND METHODS}

The three strains employed in our experiments were: strain $\mathrm{Ty}_{2}$ (S. typhi), strain $\mathrm{HB}_{3}(S$. paratyphi $B)$ and strain $\mathrm{AH}_{6}(S$. paratyphi $A)$. The $\mathrm{LD}_{50}$ of the three strains was determined by intraperitoneal injection (in saline solution) of white mice weighing $18-20 \mathrm{~g}$. and was found to be $2.5 \times 10^{7}$ to $5 \times 10^{7}$ bacteria for $\mathrm{Ty}_{2}$ and $\mathrm{HB}_{3}$ and $6 \times 10^{8}$ to $8 \times 10^{8}$ for $\mathrm{AH}_{6}$.

Oral infections were induced by means of a $2 \mathrm{ml}$. syringe to which a nylon tube was attached, thin and soft, in order to avoid perforation and wounding of the oesophagus. Shortly after anaesthetizing the mouse with ether, the mouth was held widely open with forceps. The tube was inserted deeply into the pharynx and a measured dose was administered (a method enabling us to give the exact dosage to each mouse). With the aid of the dye, Malachite green, it was found that by this method, the bacteria quickly reach the duodenum and jejunum.

For the purpose of comparison, the mice were in later experiments infected by different methods: intraperitoneally, subcutaneously and intramuscularly.

After the oral infection, the following organs were tested: spleen, liver, lungs, kidneys, mesenteric nodes, gall-bladder, oesophagus and the upper part of the jejunum as well as the blood and urine. Cultures from the above organs were grown in Kauffmann-Mueller selective medium. Before culturing the organs in this medium 0.5-1.0 ml. of blood was drawn from the heart and cultured in that medium as well. Generally, isolation of the strain by this method is possible after $24-48 \mathrm{hr}$. However, the cultures were incubated for 8 days, after which period they were discarded. A drop of the culture in Kauffmann-Mueller medium was 
plated on MacConkey or S.S. media. The strain was then fully identified by biochemical and serological tests.

An estimate of the number of bacteria was made by evenly spreading $0 \cdot 1 \mathrm{ml}$. blood (by means of an angled glass-rod spreader), on a MacConkey plate.

The number of bacteria in the spleen was determined in the following manner: after removing the blood from the heart, the spleen was taken out and macerated in a mortar-with the addition of sterile saline. The required dilutions-in volumes of $0.1 \mathrm{ml}$.-were plated on MacConkey media.

After several preliminary experiments, a dose of $5 \times 10^{9}$ bacteria was chosen for those experiments involving oral infection. This dose was given in several volumes : $0 \cdot 1,0 \cdot 2$ and $0.5 \mathrm{ml}$. In several of the experiments, mice which had been previously starved for nearly $24 \mathrm{hr}$. were employed, in the remainder the mice received their usual diet. It should be pointed out that this dose of $5 \times 10^{9}$ bacteria did not cause any clinical symptoms in the mice when given orally. However, a dose 100 times smaller $\left(5 \times 10^{7}\right.$ bacteria) injected intra-peritoneally, was found to be the $50 \%$ lethal dose $\left(\mathrm{LD}_{50}\right)$.

The organs of the mice were removed and cultured on Kauffmann-Mueller medium, at intervals varying from 2 to $3 \mathrm{~min}$. up to 40 days and more after the oral infection.

\section{RESULTS}

\section{Experiments with Salmonella typhi $\left(T y_{2}\right)$}

We performed several experiments giving the mice $5 \times 10^{9} \mathrm{Ty}_{2}$ orally after which the organs were cultured on Kauffmann-Mueller medium at an interval of 2-3 min. after infection.

The results of these experiments are shown in Table 1. As will be seen from this table, a high percentage of the bloods were positive-up to $64.5 \%$ when $0.5-1 \mathrm{ml}$. of blood was cultured in this liquid medium. When $0.1 \mathrm{ml}$. of blood was plated on MacConkey, $55 \%$ of the bloods were positive. It is interesting to note the striking

Table 1. Results of experiments 2-3 min. after oral infection with a dose of $5 \times 10^{9}$ organisms of Salmonella typhi $T y_{2}$

\begin{tabular}{lccccc}
\multicolumn{5}{c}{$\begin{array}{c}\text { Positive } \\
\text { bloods, }\end{array}$} \\
& $\begin{array}{c}\text { Positive } \\
\text { on direct } \\
\text { blating }\end{array}$ & $\begin{array}{c}\text { Positive } \\
\text { spleens }\end{array}$ & $\begin{array}{c}\text { Positive } \\
\text { livers }\end{array}$ & $\begin{array}{c}\text { Positive } \\
\text { lungs }\end{array}$ \\
Total positives & $185 / 286$ & $\mathbf{9 9 / 1 7 4}$ & $13 / 64$ & $\mathbf{3 6 / 5 0}$ & $\mathbf{2 2 / 2 9}$ \\
Percentage of positive samples & 64.5 & 55 & 20 & 72 & 75 \\
No. of experiments & 29 & 21 & 7 & 5 & 3
\end{tabular}

difference in the percentage of positive findings in the spleen $(20 \%)$ and two other organs: the liver and the lungs $(72$ and $75 \%)$. When these organs were examined over longer periods of time, the largest number of positive results was found in the spleen.

The following groups of mice were examined $3 \mathrm{~min}$. to $6 \mathrm{hr}$. after infection. The results are shown in Table 2. 
This table, compared with Table 1, shows that the percentage of positive bloods increased from 64.5 to 76 , while plate cultures showed no change in percentage. A significant difference was found in the increase of the percentage of positive spleens from 20 to 78 . No change was observed in the liver. In the lungs there was a slight decrease from 75 to $65 \%$. The table also shows the findings in the kidneys, gall-bladder, mesenteric nodes and urine.

\section{Table 2. Results of experiments 3 min. to 6 hr. after oral infection with a dose of} $5 \times 10^{9}$ organisms of Salmonella typhi $T y_{2}$

\begin{tabular}{|c|c|c|c|c|c|c|c|c|c|}
\hline & $\begin{array}{c}\text { Positive } \\
\text { bloods }\end{array}$ & $\begin{array}{c}\text { Positive } \\
\text { bloods, } \\
\text { on direct } \\
\text { plating }\end{array}$ & $\begin{array}{l}\text { Positive } \\
\text { spleens }\end{array}$ & $\begin{array}{l}\text { Positive } \\
\text { livers }\end{array}$ & $\begin{array}{l}\text { Positive } \\
\text { lungs }\end{array}$ & $\begin{array}{l}\text { Positive } \\
\text { kidneys }\end{array}$ & $\begin{array}{c}\text { Positive } \\
\text { gall- } \\
\text { bladders }\end{array}$ & $\begin{array}{l}\text { Positive } \\
\text { mesenteric } \\
\text { nodes }\end{array}$ & $\begin{array}{r}\text { Positiv } \\
\text { urine }\end{array}$ \\
\hline Total positives & $291 / 384$ & $77 / 140$ & $200 / 254$ & $91 / 120$ & $69 / 105$ & $42 / 60$ & $5 / 35$ & $9 / 20$ & $8 / 40$ \\
\hline $\begin{array}{l}\text { Percentage of positive } \\
\text { samples }\end{array}$ & 76 & 55 & 78 & 75 & 65 & 70 & 14 & 45 & 20 \\
\hline No. of experiments & 24 & 14 & 19 & 8 & 6 & 4 & $\mathbf{3}$ & 2 & 3 \\
\hline
\end{tabular}

When the blood and organs were examined in the following days, considerable changes were noted. The results are summarized in Table 3 . The table shows a decisive decrease in the percentage of positive blood cultures-14\% after $24 \mathrm{hr}$. and $1.5 \%$ after $48 \mathrm{hr}$. This, of course, is the result of the 'clearing mechanism' of the blood. The percentage of positive spleens remained high-about 62. The liver, lungs and kidneys showed a marked decrease, $40-47 \%$; the gall-bladder, about $12 \%$.

The organs and body fluids were examined daily, thus enabling us to determine exactly the period after which $\mathrm{Ty}_{2}$ could no longer be detected. A steady decrease in the percentage of positives was observed but each organ showed a different time limit during which it became sterile. It was also observed that the different organs remained positive for a comparatively long time after the blood had become negative.

The results after 4 and more days show that the blood generally becomes sterile after approximately 7 days and only a small percentage of bloods remained positive as late as the 9 th day of the experiment. The spleen became sterile after 21-22 days, the liver after 18 days, the gall-bladder after 8-9 days. The percentage of livers infected was 5 times as great as that of the gall-bladders. The percentage of positive kidneys decreased steadily and after 6 days only $25 \%$ remained positive. Similarly, a small percentage of positive urines was observed after 5 days.

Since the various organs tested were already positive after several minutes, we searched for the shortest period in which it would be possible to find $\mathrm{Ty}_{2}$ in the blood after oral infection. By cardiac puncture it was possible to shorten the period between the infection of the mouse and the blood test. In this way, it was found that already after 20-30 sec., typhoid bacilli were present in the blood. In ten additional experiments which were performed, 93 out of 144 mice $(64 \%)$ showed positive blood cultures, a percentage similar to the one found after 2-3 min. Upon direct plating of the blood $53 \%$ were positive. 


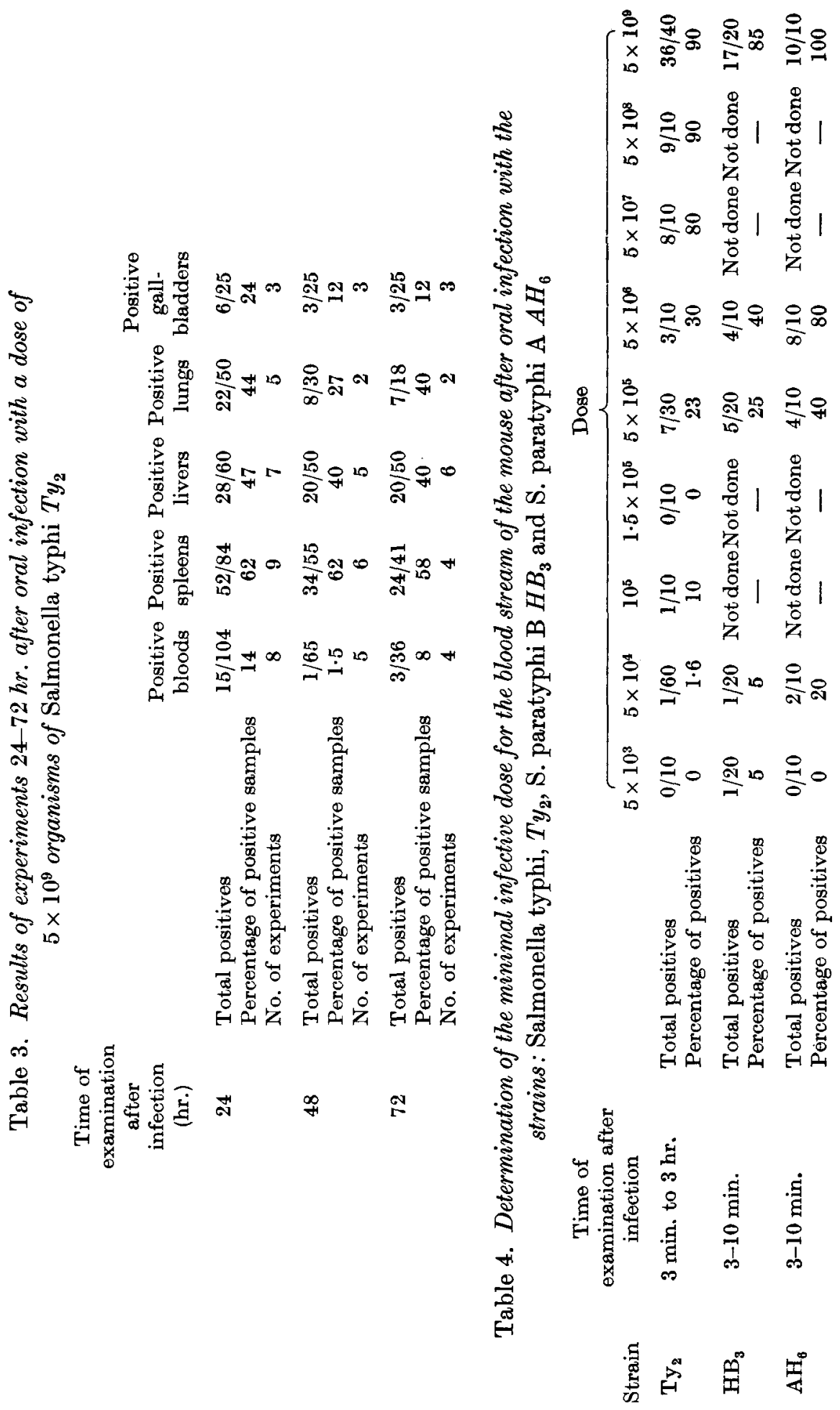


Other experiments proved that the volume of the dose $(0.1,0.2$ and $0.5 \mathrm{ml}$.), which always contained $5 \times 10^{9}$ bacteria, does not influence the velocity or intensity with which $\mathrm{Ty}_{2}$ bacteria pass from the gastro-intestinal tract into the blood stream. No difference was found with regard to the degree of infection of the blood and the various organs between the starving mice and those receiving normal diet.

In the above experiments infection was induced with a large dose of $5 \times 10^{9}$ bacteria. In the following experiments, we tried to determine the minimal infective dose (M.I.D.) of $\mathrm{Ty}_{2}, \mathrm{HB}_{3}$ and $\mathrm{AH}_{6}$ for the blood when given orally. Doses of $5 \times 10^{3}$ to $5 \times 10^{9}$ bacteria were given.

Table 5. Results of experiments 3 min. to 4 days after oral infection with a dose of $5 \times 10^{9}$ organisms of Salmonella paratyphi B $\mathrm{HB}_{3}$

\begin{tabular}{|c|c|c|c|c|c|c|}
\hline $\begin{array}{c}\text { Time of } \\
\text { examination } \\
\text { after } \\
\text { infection }\end{array}$ & & $\begin{array}{l}\text { Positive } \\
\text { bloods }\end{array}$ & $\begin{array}{l}\text { Positive } \\
\text { spleens }\end{array}$ & $\begin{array}{c}\text { Positive } \\
\text { livers }\end{array}$ & $\begin{array}{c}\text { Positive } \\
\text { lungs }\end{array}$ & $\begin{array}{c}\text { Positive } \\
\text { findings } \\
\text { in upper } \\
\text { part of } \\
\text { jejunum }\end{array}$ \\
\hline 2-3 $\mathrm{min}$. & $\begin{array}{l}\text { Total positives } \\
\text { Percentage of positive samples } \\
\text { No. of experiments }\end{array}$ & $\begin{array}{c}22 / 40 \\
55 \\
4\end{array}$ & $\begin{array}{c}20 / 40 \\
50 \\
4\end{array}$ & $\begin{array}{l}34 / 40 \\
85 \\
4\end{array}$ & $\begin{array}{c}35 / 40 \\
87 \\
4\end{array}$ & - \\
\hline $3 \mathrm{~min}$. to $4 \mathrm{hr}$. & $\begin{array}{l}\text { Total positives } \\
\text { Percentage of positive samples } \\
\text { No. of experiments }\end{array}$ & $\begin{array}{c}38 / 50 \\
76 \\
3\end{array}$ & $\begin{array}{l}35 / 50 \\
70 \\
3\end{array}$ & $\begin{array}{l}25 / 30 \\
83 \\
2\end{array}$ & $\begin{array}{c}27 / 30 \\
90 \\
2\end{array}$ & $\begin{array}{c}36 / 40 \\
90 \\
2\end{array}$ \\
\hline $24 \mathrm{hr}$. & $\begin{array}{l}\text { Total positives } \\
\text { Percentage of positive samples } \\
\text { No. of experiments }\end{array}$ & $\begin{array}{l}9 / 40 \\
22 \\
4\end{array}$ & $\begin{array}{c}27 / 40 \\
67 \\
4\end{array}$ & $\begin{array}{c}24 / 30 \\
80 \\
3\end{array}$ & $\begin{array}{c}23 / 30 \\
76 \\
3\end{array}$ & $\begin{array}{l}6 / 20 \\
30 \\
2\end{array}$ \\
\hline $48 \mathrm{hr}$. & $\begin{array}{l}\text { Total positives } \\
\text { Percentage of positive samples } \\
\text { No. of experiments }\end{array}$ & $\begin{array}{c}13 / 40 \\
32 \\
4\end{array}$ & $\begin{array}{c}31 / 40 \\
77 \\
4\end{array}$ & $\begin{array}{l}30 / 40 \\
75 \\
4\end{array}$ & $\begin{array}{c}31 / 40 \\
77 \\
4\end{array}$ & $\begin{array}{l}7 / 20 \\
31 \\
2\end{array}$ \\
\hline $72 \mathrm{hr}$. & $\begin{array}{l}\text { Total positives } \\
\text { Percentage of positive samples } \\
\text { No. of experiments }\end{array}$ & $\begin{array}{l}5 / 20 \\
25 \\
2\end{array}$ & $\begin{array}{c}15 / 20 \\
75 \\
2\end{array}$ & $\begin{array}{c}10 / 10 \\
100 \\
1\end{array}$ & $\begin{array}{l}9 / 10 \\
90 \\
1\end{array}$ & $\begin{array}{l}2 / 10 \\
20 \\
2\end{array}$ \\
\hline $96 \mathrm{hr}$. & $\begin{array}{l}\text { Total positives } \\
\text { Percentage of positive samples } \\
\text { No. of experiments }\end{array}$ & $\begin{array}{l}3 / 20 \\
15 \\
2\end{array}$ & $\begin{array}{c}14 / 20 \\
70 \\
2\end{array}$ & $\begin{array}{c}14 / 20 \\
70 \\
2\end{array}$ & $\begin{array}{l}15 / 20 \\
75 \\
2\end{array}$ & $\begin{array}{l}4 / 20 \\
20 \\
2\end{array}$ \\
\hline
\end{tabular}

The results are shown in Table 4. We can see that the M.r.D. for the blood is approximately $5 \times 10^{4}$ bacteria for $\mathrm{HB}_{3}$ and $\mathrm{AH}_{6}$ and slightly more for $\mathrm{Ty}_{2}$. A correlation exists between the size of the dose and the percentage of positive bloods. Although it was clear from the start that a dose of $10^{4} \mathrm{Ty}_{2}$, which hardly infects the blood, would not infect the organs of the mouse, we nevertheless tested thirty-spleens at time intervals of $3 \mathrm{~min}$. to $3 \mathrm{hr}$. after oral infection, with a dose of $5 \times 10^{4}$ bacteria. All the spleens were negative.

The findings after oral infection by $\mathrm{HB}_{3}$ were different in some respects from those obtained with $\mathrm{Ty}_{2} ; \mathrm{HB}_{3}$ infects the organs in a higher percentage and remains longer in the infected organs.

Table 5 summarizes the results of the experiments after the first 4 days.

Two to three minutes after oral infection, the percentage of positive bloods was 
slightly lower than in similar experiments with $\mathrm{Ty}_{2}\left(55 \%\right.$ with $\mathrm{HB}_{3}$ as compared with $64.5 \%$ with $\mathrm{Ty}_{2}$ ). However, after several hours, the percentage of positive bloods was higher for $\mathrm{HB}_{3}$ than for $\mathrm{Ty}_{2}$. After infection with $\mathrm{HB}_{3}$ the blood usually becomes sterile in 10 days; with $\mathrm{Ty}_{2}$ the period is about 7 days.

Two to three minutes after oral infection, the percentage of positive findings in the spleen is lower than in other organs-liver and lungs. Similar findings were obtained by $\mathrm{Ty}_{2}$ infection. It should be stressed, however, that the percentage of positive spleens after $\mathrm{HB}_{3}$ infection was higher than after $\mathrm{Ty}_{2}$ infections $\mathbf{( 5 0} \%$ with $\mathrm{HB}_{3}$ as compared with $20 \%$ with $\mathrm{Ty}_{2}$ ). As in the case of $\mathrm{Ty}_{2}$, there was a similar rise in positive spleens with $\mathrm{HB}_{3}$ several hours after infection $(70 \%$ as opposed to $78 \%$ with $\mathrm{Ty}_{2}$ ). This proportion of about $70 \%$ remained more or less constant during 3 weeks, and only at the end of this period was a decline observed.

The differences between $\mathrm{HB}_{3}$ and $\mathrm{Ty}_{2}$ were apparent in the findings in other organs, e.g. liver and lungs. These organs showed a high percentage of infection with $\mathrm{HB}_{3}$, not differing from that of the spleen until about the fourteenth day, in contrast to the results obtained with $S$. typhi infections which showed a decisive decrease in positive findings for these organs after 2 days. Only after 14 days was a decrease evident in the percentage of positive liver and lung cultures. This difference between the findings in spleen and other organs increased and after 28 days $60 \%$ positive spleens were found as against $10 \%$ positive livers.

Another difference between $\mathrm{HB}_{3}$ and $S$. typhi was that the spleens became negative after approximately 22 days in the case of $\mathrm{Ty}_{2}$ but a small percentage was still positive 40 days after infection with $\mathrm{HB}_{3}$ during which period there was a low percentage of positive lungs and livers.

The few experiments carried out with $\mathrm{AH}_{6}$ showed that this strain infects the organs to a less extent than the other two strains and remains in the infected organs for a shorter period.

As already pointed out, the $\mathrm{LD}_{50}$ for $\mathrm{Ty}_{2}$ intraperitoneally injected, was between $2.5 \times 10^{7}$ and $5 \times 10^{7}$ bacteria (in saline). On the other hand, the oral administration of a dose 100 times larger did not cause any clinical symptoms or deaths, an aspect which demanded a more thorough investigation.

Seven experiments were performed in which a dose of $5 \times 10^{9}$ bacteria was given orally and a count of the bacteria in the blood was made at various time intervals. Table 6 shows the results of these experiments. It will be seen that the count of $\mathrm{Ty}_{2}$ bacteria/ml. blood 2-3 min. after infection is approximately $5 \times 10^{2}$ bacteria.

The number of bacteria in the blood was also determined after longer time intervals. The results are given in Table 7 , which shows a steady decrease in the count of bacteria in the blood during the first few hours after oral infection. After $24 \mathrm{hr}$., the average was 30 bacteria per ml. blood.

An examination of the number of bacteria in the spleen, $3 \mathrm{~min}$. up to $6 \mathrm{hr}$. after oral infection with $5 \times 10^{9} \mathrm{Ty}_{2}$, showed an average of 60 bacteria/100 mg. spleen. This number remained almost constant during the first 3 days, but during the 4th day approximately $5 \times 10^{2}$ bacteria/100 mg. spleen were found.

In the following experiments a comparison was made between the count of bacteria found in the blood and spleen after subcutaneous, intramuscular and 
intraperitoneal injection with the count found after oral infection. The twelve experiments are summarized in Table 8.

The results of the twelve experiments showed that the invasion of the blood and spleen by $\mathrm{Ty}_{2}$ varied with the method of infection. By subcutaneous infection with $5 \times 10^{9}$ bacteria, the percentage of positive blood cultures and the count of bacteria in the blood were similar to those found after oral infection with the same dose of bacteria. Neither methods of infection with $5 \times 10^{4}$ bacteria lead

Table 6. Results of experiments by oral infection with a dose of $5 \times 10^{9}$ and $5 \times 10^{6}$ organisms of Salmonella typhi $T y_{2}$ and the determination of the number of bacteria in the blood stream 2-3 min. after infection

$\begin{array}{ccccc}\begin{array}{c}\text { Volume } \\ \text { of dose } \\ (\mathrm{ml} .)\end{array} & \begin{array}{c}\text { Positive } \\ \text { bloods }\end{array} & \begin{array}{c}\text { Positive } \\ \text { bloods, } \\ \text { on direct } \\ \text { plating }\end{array} & \begin{array}{c}\text { No. of bacteria } \\ \text { per I ml. blood } \\ \text { (average) }\end{array} \\ 5 \times 10^{9} & 0.5 & 6 / 10 & 3 / 10 & 370 \\ 5 \times 10^{9} & 0 \cdot 2 & 8 / 10 & 8 / 10 & 150 \\ 5 \times 10^{9} & 0 \cdot 1 & \text { Not done } & 6 / 10 & 400 \\ 5 \times 10^{9} & 0.5 & 10 / 10 & 2 / 5 & 220 \\ 5 \times 10^{9} & 0.5 & 5 / 10 & 3 / 5 & 110 \\ 5 \times 10^{9} & 0.5 & 8 / 10 & 8 / 10 & 1460 \\ 5 \times 10^{9} & 0.5 & 8 / 10 & 3 / 5 & 740 \\ 5 \times 10^{8} & 0.5 & 2 / 10 & 1 / 5 & 350\end{array}$

Table 7. Results of experiments by oral infection with a dose of $5 \times 10^{9}$ organisms of Salmonella typhi, $T y_{2}$ and the determination of the number of bacteria in the blood stream

$\begin{array}{cccc}\begin{array}{c}\text { Time of } \\ \text { examination } \\ \text { after }\end{array} & \begin{array}{c}\text { Positive } \\ \text { bloods } \\ \text { on direct } \\ \text { plating }\end{array} & \begin{array}{c}\text { No. of } \\ \text { bacteria } \\ \text { per 1 ml. blood } \\ \text { (average) }\end{array} \\ \begin{array}{c}\text { 5-60 min. } \\ 66-120 \text { min. }\end{array} & 10 / 10 & 9 / 10 & 1660 \\ 122-180 \text { min. } & 9 / 10 & 8 / 10 & 800 \\ & 9 / 10 & 6 / 10 & 170\end{array}$

to the development of a detectable bacteraemia. The percentage of positive blood cultures, tested 2-4 min. after intramuscular infection with $5 \times 10^{9}$ bacteria, was lower than that obtained by the two previous methods.

Entirely different findings were obtained after intraperitoneal infection with a dose of $5 \times 10^{9}$ bacteria. Blood, spleen and direct blood cultures were all $100 \%$ positive.

Thirty per cent of blood cultures were positive $2-3 \mathrm{~min}$. after infection with $5 \times 10^{4}$ bacteria and $90 \%$ after 5-50 min. As can be seen, the count of bacteria increased steadily to more than $10^{2}$ bacteria per ml. blood after $3-6 \mathrm{hr}$. The results obtained with intraperitoneal injection are in contrast to those obtained after oral infection; the numbers of bacteria increased during the first few hours after intraperitoneal infection, while after oral infection the number decreased.

It is important to note that an intraperitoneal dose of $5 \times 10^{4}$ bacteria does not cause any clinical symptoms. 
Our aim in the following experiments was to determine the count of bacteria in the blood and spleen of mice infected intraperitoneally with a dose of $S$. typhi, Ty of about $5 \times 10^{7}$ bacteria which is equivalent to the $\mathrm{LD}_{50}$. The final purpose of these experiments was to compare the count of bacteria in the blood and spleen after intraperitoneal infection with that obtained after oral infection with a dose 100

Table 8. Results of experiments in infection of the mouse by subcutaneous, intramuscular and intraperitoneal routes with various doses of Salmonella typhi $T y_{2}$

\begin{tabular}{|c|c|c|c|c|c|c|}
\hline $\begin{array}{l}\text { Method of } \\
\text { infection }\end{array}$ & Dose & $\begin{array}{c}\text { Vol. } \\
\text { of dose } \\
\text { (ml.) }\end{array}$ & $\begin{array}{c}\text { Time of } \\
\text { examination } \\
\text { after } \\
\text { infection }\end{array}$ & $\begin{array}{l}\text { Positive } \\
\text { bloods }\end{array}$ & $\begin{array}{l}\text { Positive } \\
\text { bloods, } \\
\text { on direct } \\
\text { plating }\end{array}$ & $\begin{array}{l}\text { No. of } \\
\text { bacteria } \\
\text { per } 1 \mathrm{ml} . \\
\text { blood } \\
\text { (average) }\end{array}$ \\
\hline Subcut. & $5 \times 10^{9}$ & $0 \cdot 1$ & 2-3 min. & $5 / 10$ & $6 / 10$ & 310 \\
\hline Subcut. & $5 \times 10^{9}$ & $0 \cdot I$ & $2-50 \mathrm{~min}$. & $17 / 20$ & $15 / 20$ & 480 \\
\hline Subcut. & $5 \times 10^{9}$ & $0 \cdot 1$ & $3-23 \mathrm{~min}$. & $9 / 10$ & $8 / 10$ & 1640 \\
\hline Subcut. & $5 \times 10^{4}$ & $0 \cdot 1$ & $2-135 \mathrm{~min}$. & $0 / 15$ & $0 / 15$ & 0 \\
\hline Intramuse. & $5 \times 10^{9}$ & 0.1 & 2-3 min. & $4 / 10$ & $2 / 10$ & 240 \\
\hline Intramusc. & $5 \times 10^{9}$ & $0 \cdot 1$ & 3-4 min. & $5 / 10$ & $3 / 10$ & 1740 \\
\hline Intraperit. & $5 \times 10^{9}$ & 0.5 & $2-3.5 \mathrm{~min}$. & $10 / 10$ & $10 / 10$ & Uncountable \\
\hline Intraperit. & $5 \times 10^{9}$ & $0 \cdot 1$ & $2-3.3 \mathrm{~min}$. & $10 / 10$ & $10 / 10$ & 5240 \\
\hline Intraperit. & $5 \times 10^{9}$ & $0 \cdot 1$ & 5-60 min. & $10 / 10$ & $10 / 10$ & Uncountable \\
\hline Intraperit. & $5 \times 10^{4}$ & 0.1 & 2-4 min. & $3 / 10$ & $0 / 10$ & 0 \\
\hline Intraperit. & $5 \times 10^{4}$ & 0.1 & 5-50 min. & $9 / 10$ & $7 / 10$ & 126 \\
\hline Intraperit. & $5 \times 10^{4}$ & $0 \cdot 1$ & $3.5-6.5 \mathrm{hr}$. & $8 / 10$ & $7 / 10$ & 800 \\
\hline
\end{tabular}

Table 9. Results of experiments by intraperitoneal infection with a dose of $5 \times 10^{7}$ Salmonella typhi $T y_{2}$ and the determination of the number of bacteria in the blood stream and spleen

\begin{tabular}{|c|c|c|c|c|c|c|c|}
\hline $\begin{array}{c}\text { Group } \\
\text { of } \\
\text { mice }\end{array}$ & $\begin{array}{c}\text { Time of } \\
\text { examination } \\
\text { after } \\
\text { infection }\end{array}$ & $\begin{array}{c}\text { Positive } \\
\text { bloods }\end{array}$ & $\begin{array}{c}\text { Positive } \\
\text { bloods, } \\
\text { on direct } \\
\text { plating }\end{array}$ & $\begin{array}{l}\text { No. of } \\
\text { bacteria } \\
\text { per } 1 \mathrm{ml} . \\
\text { blood } \\
\text { (average) }\end{array}$ & $\begin{array}{c}\text { Positive } \\
\text { spleens }\end{array}$ & $\begin{array}{l}\text { Positive } \\
\text { spleens, } \\
\text { on direct } \\
\text { plating }\end{array}$ & $\begin{array}{c}\text { No. of } \\
\text { bacteria } \\
\text { per } 100 \mathrm{mg} . \\
\text { spleen } \\
\text { (average) }\end{array}$ \\
\hline 1 & 2-3 min. & $4 / 4$ & $4 / 4$ & $3.1 \times 10^{3}$ & $4 / 4$ & Not done & Not done \\
\hline 1 & 1-9 hr. & $10 / 10$ & $10 / 10$ & $1.4 \times 10^{4}$ & $8 / 8$ & $8 / 8$ & $6.8 \times 10^{4}$ \\
\hline 1 & $24 \mathrm{hr}$. & $6 / 6$ & $6 / 6$ & $3.4 \times 10^{3}$ & $6 / 6$ & $6 / 6$ & $4.02 \times 10^{5}$ \\
\hline 1 & $48 \mathrm{hr}$. & $4 / 5$ & $2 / 5$ & $6 \cdot 10^{2}$ & $5 / 5$ & $5 / 5$ & $8 \times 10^{4}$ \\
\hline 1 & $72 \mathrm{hr}$. & $5 / 5$ & $3 / 5$ & $1.4 \times 10^{3}$ & $5 / 5$ & $5 / 5$ & $3.06 \times 10^{5}$ \\
\hline 1 & $96 \mathrm{hr}$. & $5 / 5$ & $4 / 5$ & $10^{3}$ & $5 / 5$ & $5 / 5$ & $5.8 \times 10^{5}$ \\
\hline $2^{*}$ & $24 \mathrm{hr}$. & $7 / 7$ & $7 / 7$ & $1.02 \times 10^{7}$ & $7 / 7$ & $7 / 7$ & $4 \cdot 1 \times 10^{7}$ \\
\hline
\end{tabular}

times larger $\left(5 \times 10^{9}\right.$ bacteria $)$ not causing any clinical symptoms. The mice were examined several minutes after infection and the experiment lasted $96 \mathrm{hr}$. All the mice displayed obvious clinical symptoms during the first few hours, some recovered after $24 \mathrm{hr}$. while others showed graver symptoms after this period. From the latter group, the organs were removed before death. The blood and spleen were tested in various dilutions (up to $1 / 1,000,000$ ).

The results are summarized in Table 9. Within 2-3 min. of the intraperitoneal injection of $5 \times 10^{7}$ bacteria, more than $3 \times 10^{3}$ bacteria $/ \mathrm{ml}$. blood were found; after 
1-9 hr., the number rose to $1.4 \times 10^{4}$ bacteria $/ \mathrm{ml}$. blood. During the following days, from $10^{3}$ to $3 \times 10^{3}$ bacteria $/ \mathrm{ml}$. blood were found in the mice which had recovered.

In contrast to these findings the numbers of bacteria in the spleen were much greater. After 1-9 hr., an average of $6 \cdot 8 \times 10^{4}$ bacteria $/ 100 \mathrm{mg}$. spleen was found and during the following days, the number fluctuated between $8 \times 10^{4}$ and $5.8 \times 10^{5}$ bacteria/100 mg. spleen. In spite of the large number of bacteria, the mice displayed no symptoms additional to those observed during the first few hours following infection.

In moribund mice, however, an entirely different result was obtained: a severe bacteraemia with $10^{7}$ bacteria $/ \mathrm{ml}$. blood and $4 \cdot 1 \times 10^{7}$ bactera $/ 100 \mathrm{mg}$. spleen.

\section{DISCUSSION}

The three strains: $\mathrm{Ty}_{2}, \mathrm{HB}_{3}$ and $\mathrm{AH}_{6}$, when administered orally to the mouse, behave differently from $S$. typhi-murium under similar conditions. These three strains also pass from the alimentary tract into the blood stream and thence to the various organs, but unlike $S$. typhi-murium they do not multiply in those organs and therefore no secondary bacteraemia, such as is found in the natural human disease, is apparent.

The results of dissemination of the three strains in organs of the mouse obtained in our experiment differ from those obtained by Ørskov et al. (1928a) and KroghLund (1928). Orskov et al. found that after oral adminstration of $S$. paratyphi $B$ the bacteria appeared in the mesenteric nodes during the 3rd day of the experiment and were restricted to that region. They did not find bacteria in the blood or in any other organ apart from the mesenteric nodes, and only bacteria of one strain of $S$. paratyphi $B$ were found in the liver and spleen during the 7 th day. Similar observations with $S$. typhi were made by Krogh-Lund.

In our experiments we found that the bacteria appear in the blood 20-30 sec. after oral infection with a dose of $5 \times 10^{9}$ bacteria, and a high percentage of bloods were also positive shortly after infection. However, this percentage speedily decreases. The low percentage of positive bloods found during the first few days of the experiments, in spite of the 'clearing mechanism' of the blood, is probably due to the fact that the bacteria remain viable in the intestine for a longer period than in the blood, and continue to enter the blood stream from the intestinal region.

With regard to the presence of the bacteria in the intestine, our experiments have shown that $\mathrm{HB}_{3}$ bacteria could be found for at least 16 days (we did not test longer periods) in the upper part of the jejunum, the only region tested. This observation is in contrast with that made by Orskov et al. (1928a) who found that $S$. typhi-murium and $S$. paratyphi $B$ disappeared rapidly from the intestine. It also differs from those of Seiffert (1928), who claims that a non-virulent strain quickly disappears from the intestine (the strains we tested were non-virulent for the white mouse by oral infection). However, our findings are similar to those of Mueller (1912), and Kligler \& Olitzki (1930) who found the bacteria in the intestine during the whole period of infection. 
The speed with which bacteria appear in the blood stream gives rise to the question of whether the bacteria pass from the intestine into the blood via the lymphatic system, which most research workers in this field consider to be the mode of transmission, or whether they enter the blood directly by way of the capillaries, which seems to us more likely.

It does not seem plausible that the bacteria could pass through the intestinal wall, reach the mesenteric nodes, the thoracic duct and finally the blood, within a period of $20-30 \mathrm{sec}$. by this comparatively long route; the villi of the small intestine are rich in blood vessels and at the same time constitute a large surface of absorption.

Our observations do not agree with those of Mueller, who claimed that both the virulence of the strain and the dose determine whether the bacteria pass from the intestine straight into the blood or whether they first enter the lymph nodes. We were in a position to confirm that non-virulent strains pass straight into the blood even when the dose is comparatively small, $5 \times 10^{4}$ to $5 \times 10^{5}$ bacteria, though the percentage of positive bloods is lower than after oral infection with a larger dose.

The finding of only $20 \%$ positive spleen cultures $2-3 \mathrm{~min}$. after oral infection with $5 \times 10^{9} \mathrm{~S}$. typhi, as opposed to $72 \%$ positive liver cultures after the same period may indicate that a route exists by which the bacteria pass from the intestine to the organs via the blood. It is likely that the bacteria pass from the intestinal wall to the portal veins and thus reach the liver before appearing in the spleen.

A comparison of the count of bacteria in the blood and spleen of mice which have received a dose of $5 \times 10^{7}$ bacteria by the intraperitoneal route with the numbers of bacteria appearing after the oral administration of a dose 100 times larger, explains why the mice infected in the latter manner do not die or even show any clinical symptoms. Due to the limited penetration of bacteria through the intestinal wall into the blood stream even after a dose of $5 \times 10^{9}$ bacteria, the bacterial concentration (during a short period) is too small to cause sufficient damage to the various organs to lead to the development of clinical symptoms. The mouse's defensive system is quite competent to cope with this low concentration number of micro-organisms which cannot be compared with the high concentration found in the blood and spleen of mice infected intraperitoneally with $5 \times 10^{7}$ bacteria, a mode of infection resulting in death.

According to Olitzki \& Olitzki (1958), the M.I.D. of $S$. paratyphi $A$ (the avirulent strain $\mathrm{HA}_{1}$ and the extremely virulent strain 2455) for the blood of the white mouse when injected intraperitoneally, is $10^{4}-10^{5}$ bacteria, the M.I.D. for spleen and liver being $10^{3}-10^{4}$ bacteria. They found no proportional ratio between the method of infection (intraperitoneal injection) and the concentration of bacteria in the liver and spleen. Thus, they found after infection with doses of $10^{3}-10^{5}$ bacteria by this method, less than $10^{2}$ bacteria in the liver and spleen after 3-5 days. After a dose of $10^{6}-10^{7}$ bacteria, they found $10^{2}-10^{3}$ bacteria in those organs. A dose of $10^{8}$ bacteria of the virulent strain resulted in a sudden rise in the number of bacteria found in the spleen, up to $10^{4}-10^{5}$. A dose of only $2.5 \times 10^{8}$ bacteria caused death; a post-mortem examination of the mice (employing both strains) revealed $7 \times 10^{7}$ bacteria in the spleen.

In our experiments with the intraperitoneal injection of $S$. typhi, there were 
similar findings. We did not estimate the numbers of bacteria in the spleen after infection with S. paratyphi $A$ or $S$. paratyphi $B$.

After intraperitoneal injection of $5 \times 10^{4} \mathrm{Ty}_{2}$, nearly $10^{3}$ bacteria $/ 100 \mathrm{mg}$. spleen were found after 3-6 hr. and $10^{5}$ to $5 \times 10^{5} / 100 \mathrm{mg}$. spleen, $24-96 \mathrm{hr}$. after a dose of $5 \times 10^{7}$ bacteria $\left(\mathrm{LD}_{50}\right)$. However, examinations of moribund mice which had received the same dose revealed $4 \times 10^{7}$ bacteria/100 $\mathrm{mg}$. spleen after $24 \mathrm{hr}$. (nearly the same number we started out with). This number is approximately the same as that found by Olitzki \& Olitzki during post mortem examination of mice infected with $S$. paratyphi $A$.

An entirely different picture was observed after oral infection. By this method, the M.I.D. of S. paratyphi A, S. paratyphi $B$ and $S$. typhi for the blood stream is about $5 \times 10^{5}$ bacteria. When a dose of $5 \times 10^{9}$ S.typhi $\left(\mathrm{Ty}_{2}\right)$ was administered, there were approximately $5 \times 10^{2}$ bacteria/ml. blood and about $10^{2}$ bacteria in the spleen during the first few hours. After 3-4 days, the count of bacteria in the spleen rose to $5 \times 10^{2}$ bacteria $/ 100 \mathrm{mg}$. spleen.

These findings illustrate the difficulties of attempting to compare the counts of bacteria in the blood and spleen after intraperitoneal and oral infection when using a strain which is not a natural pathogen for the mouse.

\section{SUMMARY}

A dose of $5 \times 10^{9} \mathrm{~S}$. typhi (strain $\mathrm{Ty}_{2}$ ) and S. paratyphi $B$ (strain $\mathrm{HB}_{3}$ ) administered to white mice orally, caused an infection of various organs of the mouse, namely: spleen, liver, kidneys, lungs, gall-bladder, mesenteric lymph nodes, jejunum and of the blood stream. The percentage of infected spleens was higher than that of other organs.

With the above-mentioned dose of $\mathrm{Ty}_{2}$, the infection of the liver was found to be five times higher than that of the gall-bladder. The infection of the latter lasted for about 8-9 days, whereas that of the liver for 18-19 days.

The bacteria appeared in the various organs: liver, spleen, kidneys, and lungs in about $2 \mathrm{~min}$. after oral infection, and in the blood stream after about $20 \mathrm{sec}$.

The speed and intensity of the invasion of micro-organisms from the gastrointestinal tract to the blood stream depends neither upon the volume of the dose $(0.5 \mathrm{ml}$. or $0.1 \mathrm{ml}$.$) , nor upon the content of the mouse's stomach.$

The M.I.D. for the blood stream of the mouse by oral infection is about $5 \times 10^{5}$ bacteria for $\mathrm{Ty}_{2}, \mathrm{HB}_{3}$ and $\mathrm{AH}_{6}$.

In blood samples collected by cardiac puncture 2-3 min. after oral infection, an average of $5 \times 10^{2}$ micro-organisms $/ \mathrm{ml}$. blood was found. The count of bacteria increased and reached its peak after $20 \mathrm{~min}$. (about $3 \times 10^{3}$ bacteria). After that period, the number decreased: $1.6 \times 10^{3}$ after $1 \mathrm{hr}$., $8 \times 10^{2}$ after $2 \mathrm{hr}$. and $1.7 \times 10^{2}$ after $3 \mathrm{hr}$. In spite of this considerable decrease, the blood did not became sterile until after several days.

In the infected spleen (by oral infection) an inverse process was observed: at the beginning only a small number of micro-organisms was found (about $5 \times 10 / 100 \mathrm{mg}$. spleen), but afterwards the number of bacteria increased $\left(1.2 \times 10^{2}\right.$ after $24 \mathrm{hr}$. and $5 \times 10^{2}$ after 4 days). 
In mice infected by the subcutaneous route with a dose of $5 \times 10^{9}$ bacteria, the number of micro-organisms in the blood stream did not differ significantly from that found after oral infection, whereas infection by intraperitoneal route caused a severe infection. When $5 \times 10^{7}$ micro-organisms $\left(\mathrm{LD}_{50}\right)$ were administered by intraperitoneal route, $10^{7}$ bacteria appeared in the blood stream of the moribund mice while in the spleen about $4 \cdot 1 \times 10^{7}$ were found.

The author wishes to express his appreciation to Prof. I. Gurewitch and to Dr R. Rozansky from the Department of Clinical Microbiology, the Hebrew University-Hadassah Medical School, Jerusalem, for their advice and criticism.

\section{REFERENCES}

Kligler, I. J. \& OLITZKI, L. (1930). Z. Hyg. Infektkr, 111, 711.

KligLeR, I. J. \& OLITZKI, L. (1931). Amer. J. Hyg. 13, 349.

Krogh-LuND, G. (1928). J. Immunol. 59, 406.

MUELIER, M. (1912). Z Zbl. Bakt. 62, 335.

OlitzKI, A. L. \& OnITZKI, Z. (1958). Bull. Res. Coun. Israel, 7E, 105.

Ørskov, J., JENSEN, K. \& KoBaYASH, K. (1928a). Z. ImmunForsch. 55, 34.

ØRSKOV, J. \& MoLTKE, O. (1928b). Z. ImmunForsch. 59, 357.

SeIFTERT, W. (1928). Arch. Hyg. 101, 117. 